\title{
The Implication of Indonesia's IU U Fishing Policy in Natuna Territorial Waters towards South China Sea Geopolitics
}

\author{
Silvia Dian Anggraini, Indra Kusumawardhana, Iqbal Ramadhan \\ International Relations Department \\ Universitas Pertamina \\ J alan Teuku Nyak Arief, Kebayoran Lama, J akarta 12220 \\ iqbal.ramadhan@ universitaspertamina.ac.id \\ Submitted: 24 May 2018; accepted: 21 November 2018
}

\begin{abstract}
Abstrak
Agenda era kepemimpinan Presiden Joko Widodo menyasar langkah-langkah tegas dalam melindungi keamanan dan kedaulatan maritim Indonesia; terutama kedaulatan dan keamanan maritim di sekitar teritorial laut. Namun, implementasi ini menghadapi tantangan terkait pelanggaran kedaulatan. Salah satunya adalah pencurian ikan oleh kapal-kapal nelayan asing yang mengancam jumlah cadangan ikan di perairan Indonesia. Berhadapan dengan ancaman tersebut, komitmen Indonesia untuk menjaga kedaulatan dan keamanan maritim nampak dari pengambilan kebijakan 'tenggelamkan kapal' oleh Kementerian Kelautan dan Perikanan (KKP), yang dipimpin oleh Susi Pudjiastuti sejak tahun 2014. Dalam konteks polemik Laut China Selatan yang berhubungan dengan perairan wilayah Indonesia, terutama di seputar perairan Natuna, kebijakan tersebut memiliki implikasi signifikan terhadap geopolitik Laut China Selatan. Pertanyaan yang muncul adalah apa implikasi kebijakan 'Sink the Vessels' terhadap geopolitik maritim di Laut China Selatan? Dengan menggunakan pendekatan strukturasi dan geopolitik, artikel ini menyatakan bahwa kebijakan 'IUU Fishing' Indonesia meningkatkan kompleksitas keamanan maritim di Laut China Selatan. Dalam konteks kebijakan ini, interaksi di Laut China Selatan pada akhirnya mengarah pada penguatan perilaku realisme politik di antara negaranegara yang berpotensi konflik dengan Indonesia di perairan Natuna.
\end{abstract}

Kata kunci: Indonesia, IUU Fishing, tenggelamkan kapal, Laut China Selatan, geopolitik, strukturasi.

\begin{abstract}
A bstract
The agenda of Jokowi's administration demands a strong measure to protect maritime security and sovereignty of Indonesia; especially its national sovereignty and maritime security in the vast boundary of Indonesian territorial waters. However, the implementation faces challenges related to violations of sovereignty in the territorial waters. One of them was due to the rampant illegal fishing activities that threaten the sufficiency of the fish stock. Exposed to such threat, Indonesia's commitment to secure its maritime sovereignty was strongly projected by the emergence of a 'Sink the Vessels' policy by the M inistry of M arine Affairs and Fisheries (KKP), chaired by Susi Pudjiastuti since 2014. In the context of the South China Sea polemics which shows the relationship with the territorial waters of Indonesia in Natuna, the policy has significant implication to the South China Sea maritime geopolitics. The question is what the implications of the 'Sink the Vessels' policy toward maritime geopolitics in the South China Sea. Using structuration and geopolitics approaches, this article argues that Indonesia's IUU Fishing policy enhances the complexity of maritime security in the South China Sea which ultimately leads to the strengthening of political realism behaviour among countries whom potential to conflict with Indonesia in the context of IUU Fishing in Natuna waters. Keywords: Indonesia, IUU Fishing, sink the vessels, South China Sea, geopolitics, structuration.
\end{abstract}

\section{INTRODUCTION}

At the beginning of Joko W idodo's administration in 2014, the world was startled by Indonesian firm policy to sink domestic and foreign fishing vessels caught stealing

fish in Indonesian waters. The policy is known as 'Sink the Vessels,' led by Susi Pudjiastuti as the M inister of Marine Affairs and Fisheries. The minister has been known 
as an assertive person in completing her duties. The 'Sink the Vessels' policy is considered as I ndonesia's strong commitment to implement 'G lobal M aritime Axis' agenda by President Joko W idodo that demands the ability of Indonesia to secure its maritime security and national sovereignty. The perspective used was originated from 'reasserting the long-standing archipelagic outlook.' President $W$ idodo values the waters surrounding the Indonesian archipelago for its economic potential and national strength, rather than deems it as a natural disadvantage (G indarsah \& Priamarizki, 2015). The policy is considered highly important by the Indonesian government due to Indonesia's geographical terrain. A s an archipelagic state, Indonesia is exposed to rampant illegal fishing activities which lead to the decline of fish stocks in the territorial waters of Indonesia (C hapsos \& M alcolm, 2017; C onnelly, 2015; Febrica, 2017; Gindarsah \& Priamarizki, 2015; H ongzhou, 2015; Nainggolan, 2015; N egara \& Das, 2017). Locations with the highest level of illegal fishing activity are identified in A nambas and $N$ atuna waters. In the span of 2014, 78 foreign fishing vessels detained for illegal fishing activity in the area. According to A nambas Vice Regent, $A$ bdul $H$ aris, the number of fish theft activities threatened the occupation of $90 \%$ of A nambas people who work as fishermen (Rohingati, 2014).

The illegal fishing activities of foreign fishermen in Indonesian waters raise polemics. The policy of detonating foreign fishing vessels caught stealing fish in Indonesian waters, especially in Natuna, triggered responses from the origin countries of the vessels. M eanwhile, the current maritime security of Southeast A sia is facing a potential threat from maritime delimitation boundary disputes in the South China Sea. Researchers argue that a unique contestation revealed after Indonesia implemented the 'Sink the Vessels' policy, especially in N atuna. From the geopolitical approach, it is apparent that the involvement of countries related to the South China Sea conflict is inevitable (for instance $\mathrm{C}$ hina and Vietnam as two disputed states over territorial claims in the South C hina Sea whose fishermen have been heavily highlighted in fish theft activities). Given the background, this article aims to analyse the implication of IUU Fishing Policy in Indonesia toward maritime geopolitics of the South China Sea.
This article argues that the policy created a stronger political realism of states whose fishermen involved in illegal fishing in Natuna waters. This situation leads to the creation of anarchy system in the South C hina Sea that was covered by conflictual and rational dimension. Not all states whose vessels had sunk behave reactively like $\mathrm{C}$ hina. Several states' behaviour, such as Vietnam and M alaysia, were based on the consideration of the existing threat in the South China Sea.

\section{THEORETICAL FRAMEWORK}

ANALYSING THE IMPLICATION OF IUU FISHING POLICY THROUGH TWO THEORETICAL APPROACHES

This paper analyses Indonesia's IU U Fishing Policy by combining two theoretical frameworks to approach the implication of the policy within $\mathrm{N}$ atuna territorial waters towards the geopolitics of the South China Sea. Firstly, this paper utilizes structuration theory by A nthony $G$ iddens as a fundamental framework to understand the international system revealed around $N$ atuna waters. Thereafter, this paper chooses to exert G eopolitics approach by Ralf Emmer to explain the geopolitics of $N$ atuna position related to the South $\mathrm{C}$ hina Sea disputes. The preference was based on two approaches that accommodate the research urgency to capture the dynamic of the issue comprehensively; particularly regarding states response to maintain their existence under the threat of interstate relations in the international system which heavily influenced by geopolitical paradigm. In other words, Indonesian response to formulate a firm policy to tackle illegal fishing, whether inside or outside Indonesian territorial waters, is a behaviour taken based on the perception of threat. $\mathrm{H}$ owever, the involvement of foreign fishers triggered the need to look at the external interaction between states whose fishermen captured, and their vessels sunk for illegal fishing. Thus, the policy could not be overlooked because of its tangible implication to the international system in the South C hina Sea which geographically closes to Natuna waters.

Starting the discussion from G iddens' theoretical framework, analysing phenomena which closely related to security studies is an uncommon preference, particularly because of his background as a sociologist from London 
School of Economics which represents British School in understanding globalisation and modernity. This article, however, regards Giddens' structuralism approach is influential in dismantling the relation between $\mathrm{N}$ atuna and the South China Sea which located in the same international system. If an international system is perceived as a media for states to articulate their existence, thus, the international system is equal to the social system. A ccording to Giddens, intensified social relations signified by shaping each other (instead of merely influencing the other) has connected human (as an agent)-with short coverage yet high persistence-to the society (as structure) which constitutively influence each other. Regarded as G iddens' masterpiece, this theory is frequently discussed in his book titled The Constitutions of Society: 0 utline of the Theory of Structuration (1986). This approach is significant in revealing how repetition and interaction from agent and structure will eventually create a structure. According to Barker (2011), structuration encompasses three dimensions. The first dimension is an interpretation which pronounces a manner of understanding. The second dimension is morality or a precise direction to express how things should be done. The third is power in acting by stating agent's way to achieve a wish. Duality in a structure (not dualism) constructed in a social system becomes an important factor of Gidden's approach to understand the phenomena in this research. States involved in the maritime constellation of South $C$ hina Sea are agents who produce a structure in the region. $O \mathrm{n}$ the other hand, $\mathrm{N}$ atuna has gained importance in the conflict of the South $\mathrm{C}$ hina Sea due to its geographical status as an outer island in Indonesia. This is al so because international system is a social system which can be measured by the interaction within it.

The significant aspects of a sovereign nation concept are understanding, comprehension, and awareness of each individual state about a nation's sovereignty. The comprehension and awareness related to space and borders are a manifestation of the sovereignty of a nation. The strategic value of space and borders is essential for the unity of a nation. A s expressed by Ratzel (1940), a reputable geographer, emphasized that the apprehension of a nation toward the conception of territory will determinethe size of the state. The value of space in this context will only ap- pear if there is anyinteraction or social process that formed a consensus about the space utility. M entioned by Agnew and C robridge (2002), geography may 'matter,' but only as a moment in which abstract universal social processessuch as social stratification, statebuilding, and ideological hegemony-are revealed in space. Given the importance of space and the social interaction that formed it, it is essential to maintain the unity of a territory. Stated by Malmberg (1992: 117-23), "Even for some who claim that 'space matters,' therefore, it matters only contingently rather than necessarily."

Departed from those understandings, this article highlights $\mathrm{N}$ atuna's geographical proximity to the South $\mathrm{C}$ hina Sea and the geopolitical dynamic in the region. Therefore, the second theoretical framework in this article uses maritime and geopolitics approaches as a tool to measure the implication of Indonesian policy in the Natuna waters in tackling the fish theft and its relation to the South C hina Sea geopolitical circumstances. As stated by Ralf Emmers (2009: 9), there are three primary attributes in geopolitical approach, namely "The interpretation of territory, natural resources, and the distribution of power is based on a material and an ideational reading of their role in international security relations." The first attribute, according to Emmer, is the territory: "Territory is associated with statehood, national boundaries, territorial claims, and nationalism. Territory provides economic and strategic advantages to a state by increasing its political leverage in the international system" (Emmers, 2009: 10).

State as a historical unit emerged in human civilization, interlinked with the sovereignty concept of a nation, demands a clear and rigid territorial border to secure the state's legitimation in international politics. Furthermore, the clarity of territorial border is a strategic sector in providing benefit and increasing Indonesian bargaining position in global political affairs. On the other hand, natural resources according to Emmers, interpreted as "Natural resources and energy needs have traditionally influenced the foreign policy objectives of states. Thequestion of natural resources has shifted from the low politics of domestic production and consumption to the high politics of national security" (Emmers, 2009: 11). In this manner, Emmers attempted to highlight that natural resources (in this 
context is fishes) should bea priority for national security.

In accordance with Emmers' view, A mitav Acharya (2002: 324) argues that "The tendency of security studies to focus on a particular segment of the international system to the exclusion of another is ironic given the fact that it is in the neglected arena that the vast majority of conflicts have taken place." Security issues faced by the third world countries are entirely different with predominant paradigm about security in regional studies. Subse quently, in the third world countries, the nature of national security appeared merely as a dubious symbol, compare to the value of national security in the developed country with more advanced governance (C hristoper \& M eng, 2011). A charya explained further about resource scarcity, overpopulation, underdevelopment, and environmental degradation was at the heart of insecurity in thethird world. Given the significance of economic development and wellbeing, economic development is eventually perceived as an influential factor in national security.

Given the fact that natural resources are fundamental for third world countries, Emmers proposed the third dimension, distribution of power which explained as follows,

"In order to offer a unified concept, this discussion briefly describes this third geopolitical variable by referring to both a classical realist interpretation of the power phenomenon and more recent interpretations of its current rolein international security relations. Yet, it should be noted that this volume primarily adopts a realist view of the concept, understood through its military aspect. This discussion also concludes with a review of another concept central to realism: the balance of power" (E mmers, 2009: 12).

Emmers' approach emphasized the geopolitical context which highly influenced by Hobbesian realism which describes the power relation for actors in international affairs. At this point, the geographical proximity between $N$ atuna waters and the South $C$ hina Sea increases the plausibility of Indonesia to get involved in regional disputes. This view is supported by Asia-Pacific Regional Security Assessment 2016 report. It revealed that "M aritime security in the Indo-Pacific region is a complex subject, spanning a range of challenges from the tensions in the South China Sea through other territorial disputes to diverse"
(IISS, 2016, para. 1). Therefore, comprehension regarding the unstable security condition due to border disputes in the region is essential to understand the dynamic of relations between Indonesia, C hina, and Vietnam in the South C hina Sea disputes. Natuna as a northern gate in the Indonesian border appears to drag Indonesia into a prolonged conflict in the South $\mathrm{C}$ hina Sea dispute.

\section{RESULT AND ANALYSES}

NATUNA POSITION IN THE SOUTH CHINA SEA: A GEOPOLITICAL CONTESTATION

This section provides an insight into geopolitical architecture of Indonesia within the South $\mathrm{C}$ hina Sea disputes. A nalysing this geopolitical architecture of the South China Sea disputes becomes important due to the strategic position of Natuna as an integral part of Indonesia-the largest archipelagic country-and one of the biggest economic powers in the South East A sia. This brings certain consequences, particularly due to its proximity to the conflicting area of the South C hina Sea.

The structure of this section will be divided as follows; firstly, it describes the conceptual understanding related to geopolitics discourse as a theoretical formulation codified into an intellectual discussion. Secondly, the chapter will discuss the geopolitical architecture of the South China Sea. Finally, the conclusion will be delivered by linking $N$ atuna as archipelago clusters in northern Indonesia and the South China Sea disputes.

G eopolitical architecture in this context is understood as how state accesses, manages, and regulates the dynamic of territory within their sovereignty border and its interaction in cross-border dimension. Stated by Doods (2007: 55), "G eopolitical architecture is generally seen as the ways in which states access, manage and regulate the intersection of territories and flows, and, in so doing establish borders between inside/ outside and domestic/ international." H owever, established geopolitics-related studies only highlighted the importance of geographical context as a security tool of the foreign policy of a state (K asperson \& M inghi, 2011). G eopolitics paradigm should also embrace the perception of politic and security elites regarding the nature of their territory, known as 'political-geographical mental maps' (Muir \& Paddison, 1981). There- 
fore, there is an urgeto portray geopolitical architecture in a flexible way instead of scrutinizing spatial and political dimension. This also should be regarded from the perspective of geographical dimension from the context of social, economic, culture, politics, and security.

Geographically, the South C hina Sea encompasses waters and land from two main archipelagos, Spratly and Paracels Islands, and M acclesfield River and Scarborough coral, ranging from M alacca Strait to Tai wan Strait. G iven the wide landscape and the history of territory acquisition of nearby states such as C hina, Taiwan, Vietnam, the Philippines, and Brunei Darussalam are tangled in claims and acquisition for partial or entire waters area. Indonesia was not originally one of claimant state but turned the intention to claim the area since $C$ hina declared an absolute claim for the waters in 2012. The South C hina Sea is strategic with abundant natural resources. Interstate conflict in the region occurred since the 1970s, recurring in the 1980s, 1990s, 2010s, until present. H owever, it could not be denied that in the past, the claimant parties from $C$ hina and $V$ ietnam, and other claimant states have recorded as a claimant who seeks control in the area.

The fact that the South China Sea has tremendous potential in natural resources, including mineral, gas, and oil, have been revealed to the world. C hina is strongly optimistic about these potencies of natural resources and has conducted intensive research in the area. Based on the Energy Information Administration (EIA) Report, China estimated that the South $C$ hina Sea possesses 213 billion barrels of oil reserve, which is equal to ten times of the U nited States (U S) national oil reserve. The U S scientists estimate that there is an oil reserve equivalent to 28 billion barrels of oil in the waters. Report from EIA revealed that the biggest reserves originated from natural gas, reaching 900 trillion cubic, or equal to $Q$ atar's national oil reserves. Besides, the South $\mathrm{C}$ hina Sea waters are also the main navigation route for various states in the surrounding area in the hunt for fish (EIA, 2013).

The claim disputes over territorial sovereignty in the South China Sea converged waters and land into two areas, Paracel and Spratly Islands. In the area, lays uninhabited islands, atoll, and coral. The disputed areas range a hundred miles from southern to the eastern side of $\mathrm{H}$ ainan
Province. C hina's claim on the area is based on their occupation from 2000 years ago when Paracel and Spratly Islands were part of the $C$ hinese. According to the $C$ hinese Government, they published a map with detailed information about $C$ hina's claim to the South C hina Sea in 1947. ${ }^{1}$

There are six parties directly involved in the disputes: China, Tai wan, the Philippines, Brunei D arussalam, V ietnam, and M alaysia. These parties have overlapped data to prove their claims. Vietnam built their claims based on historical record, continental shelf, and economic exclusive zone regulated in UNCLOS. In their perspective, Paracel and Spratly I slands were under the rule of $\mathrm{N}$ guyen Dynasty lead by $\mathrm{G}$ ia Long Emperor from 1801-1802, just until before the French colonization took place (Anh, 2014). The Philippines also used historic, proximity, invention, relational approach, and U N CLOS data to support their claim. Several islands in Spratly were once utilized as Japanese $N$ avy base for military operation in South East A sia in the World War II. After Japan had been defeated, the newly independent Philippines declared their intention to utilize the island. Thus, the Philippines first made their claim in the $U$ nited Nations $G$ eneral Assembly. ${ }^{2}$

H owever, the agreement did not explain details regarding the disputes in Spratly Islands, and only displayed the willingness to resolve the problem in a peaceful manner, yet leaving the discussion about the core problems in nation's sovereignty. G iven the border uncertainty between claimant states, the conflicting parties still actually had the opportunity to maximize their territorial claims. This makes the possibility of open conflict in the area is prone to increase (U sman \& Sukma, 1997). For example, the Philippine government had issued a presidential decree Number 1956, demanding the right of Spratly I slands.

$M$ alaysia al so listed three islands from southern Spratly to their maritime map. Meanwhile, $\mathrm{C}$ hina included two clusters of $\mathrm{U}$-shaped islands to their territory in $\mathrm{M}$ aritime Constitution dated 25 February 1992. The situation prolonged until July 2011 where C hina protested to the Philippines' plan to explore oil and gas in the waters. The Philippines had invited foreign investors to explore 15 potential points. $C$ hina questioned the area number 3 and 
number 4 (see Figure 1) in the northern Palawan Province the Philippines, 820 kilometres in the southwest of $\mathrm{Ma}$ nila. 0 ne area located only 79 kilometres from the western side of Palawan Islands. The Philippine G overnment had stressed that the area is under the Philippines territory (Kemenhan, 2011). O ther than six claimants, states outside the region also have enormous attention to the South C hina Sea territory.

The interests of states outside the area of the South China Sea increase the complexity of the conflict. The A ssociation of Southeast A sian Nations (ASEAN) decided to get involved in the disputes by responding to the occurring conflict in the area. In $22^{\text {nd }}$ July 1992, Foreign M inisters of ASEAN countries adopted the ASEAN Declaration of $C$ onduct on the South $C$ hina Sea which suggests all the involved parties to resolve the conflict in a peaceful manner based on the principal of Treaty of A mity and Cooperation (TAC). Furthermore, ASEAN attempted to resolve the South $C$ hina Sea conflict with various strategies such as discussing the South China Sea issues in ASEAN Regional Forum (ARF), ASEAN Summit, or bring ing the issue to the international legal framework. In 1994, 2001, and 2011, ARF conducted a series of discussion about the South China Sea disputes. The issues are taken into ASEAN Summit four times: in Summit V, XI, XVII, and $X I X$. ASEAN also demonstrated various conflict resolution strategies such as conferences, seminars, and joint working groups (Thayer, 2012).

U ntil the date, ASEAN and China had achieved formal agreement called Declaration of Conduct ( $D \circ C$ ) signed in 2002. The signatory countries should comply with the rules to control the activities that could complicate or increase the tension in the region, such as sending people to inhabit the area. C laimant states also agreed to promote natural sources in the conflicted states through the possibility of cooperation in exploring the gas and oil in Spratly Island as the initial step to resolve the problem (Claudia, 2012; Kemenhan, 2011). H owever, the efforts taken have not succeeded in preventing the provocative activities of claimant states.

Indonesia as one of the ASEAN members has attempted to resolve the problem of the South China Sea since the 1980s. Indonesia has actively participated in solving the dispute through the governmental or non-governmental way. The Indonesian government also proposed $\mathrm{D} O \mathrm{C}$ and encouraged $\mathrm{C}$ ode of $\mathrm{C}$ onduct ( $\mathrm{C} \mathrm{OC}$ ) managed by ASEAN and China in 2002. However, DoC was not yet able to supervise claimant states to stop doing provocative action. Thus, in 2012 Indonesia proposed Zero Clean Draft, regarded as an initial step for ASEAN states and China to sit in one table to solve the problem after a deadlock in the 45th ASEAN M inisterial Meeting (AM M) in Cambodia, 2012. Zero clean draft incorporates the Indonesian proposal about how conflicting states should behave in the proper manner. This draft encompassed proposal to ASEAN members and $C$ hina. The draft was not intended to strengthen the claims of any party, but wish to provide details on how all parties should behave to achieve the conflict resolution (Kompas, 2012).

The Indonesian government also responds to many incidents which triggered tension in the South China Sea area. In an annual speech in 2013, Indonesian Foreign Minister, Marty $\mathrm{N}$ atalegawa highlighted various actions undertook by Indonesia in 2012 in preventing armed conflict in the South China Sea territory and attempted to converge ASEAN members' outlook about the South China Sea. Should any difference occurred in the common perspective of ASEAN members, Indonesia responded it by demonstrating shuttle diplomacy to consolidate ASEAN position according to six-point principles. Indonesian diplomacy encouraged a comprehen sive implementation of $\mathrm{DOC}$ including the regional $\mathrm{COC}$ through the basic agreement of $\mathrm{COC}$ and its initial proposal (Natal egawa, 2013).

Indonesia's intention to be a mediator in the South China Sea conflict is a manifestation of the country's foreign policy under the administration of Susilo Bambang Yudhoyono. The foreign policy in Yudhoyono administration emphasized the significance of multilateral diplomatic to create the image of middle power in the international system in the $21^{\text {st }}$ century. ${ }^{3}$ The interpretation of free and active policy was adjusted to the international circumstances where the shift of global power to A sia as an interpretation of the 'active' principle. There were at least three metaphors reflected on the foreign policy alteration at that time. The first was 'navigating a turbulent ocean,' the se- 
cond was 'all directions foreign policy' and the last was 'a thousand friends and zero enemies. ${ }^{4}$ It was apparent that in Yudhoyono administration, there were few or nearly no diplomatic activities in the maritime sector. It was argued that this was because Indonesia preferred to avoid direct involvement in the South China Sea conflict. In the period, Indonesia did not want to be considered as part of the dispute (Rosyidin, 2017).

U nder the Jokowi administration, Indonesian approach to the South C hina Sea conflict had shifted. O riginal intention to seek peaceful resolution for the disputes in the region has altered to be a policy that serves Indonesian national interest in Natuna waters, evoking disapproval from China (C hen et al., 2014; C onnelly, 2015; H amzah, 2015; Pattiradjawane, 2015; Ristian \& Supriyanto, 2015; Rosyidin, 2017; Sambhi, 2015; Weatherbee, 2016). The approach exemplifying the reality of South C hina Sea disputes has become closer with Indonesian waters territory. The realism of Indonesian politic in securing the natural resources had set $\mathrm{N}$ atuna to be the flashpoint of various interests between claimant states. G iven the anarchical situation of international system, Indonesia decided to be assertive in responding to the conflict.

Indonesia as a longestablished agent who preserved the image of 'an honest broker' in the South C hina Sea maritime structure experienced many challenges regarding the territory claim (C onnelly, 2016). The behaviour shift shown by Indonesia in responding various maritime issues had alarmed many countries whose fishermen were caught in Natuna waters. This article captures that the shift has two important consequences for Indonesia. Firstly, Indonesia intended to walk solely to realize its aims as the world maritime axis by emphasizing nation's maritime sovereignty. At the same time, there is a growing consideration if Indonesia had decided to overlook regional solidarity, particularly for states who objected China's unilateral claim of the South China Sea territory.

The argument is inherent with Aaron L. Connelly's statement (2016: 1) in his work titled Indonesia in the South China Sea: $\mathrm{G}$ oing it A lone, expressed that " $U$ nder President Jokowi, Indonesia's approach to the South China Sea disputes has moved from that of an active diplomatic actor seeking a peaceful resolution to the broader disputes, to one primarily focused on protecting its own interests around the N atuna I slands while not antagonising $C$ hina." For instance, on 17 June 2016, a small Indonesian Navy corvette, theKRI I mam Bonjol, encountered at least seven $C$ hinese fishing boats and two much larger $C$ hinese $C$ oast Guard vessels in Indonesia's Exclusive Economic Zone (EEZ) near the remote $N$ atuna Islands (A ssociated Press, 2016). The Natunas are the northernmost point of the Indonesian archipelago, between Borneo and the M alaysian Peninsula, stretching into the far southern end of the South C hina Sea. Neighbours havelong acknowledged the waters north of the Natunas as part of Indonesia's EEZ, but the C hinese Foreign M inistry has since the $1990 \mathrm{sim}$ plied-and in 2016 for the first time openly declared-that they are 'traditional Chinese fishing grounds. ${ }^{5}$

\section{Figure 1. Map of B order D elimitation in $\mathrm{N}$ atuna with the South China Sea}

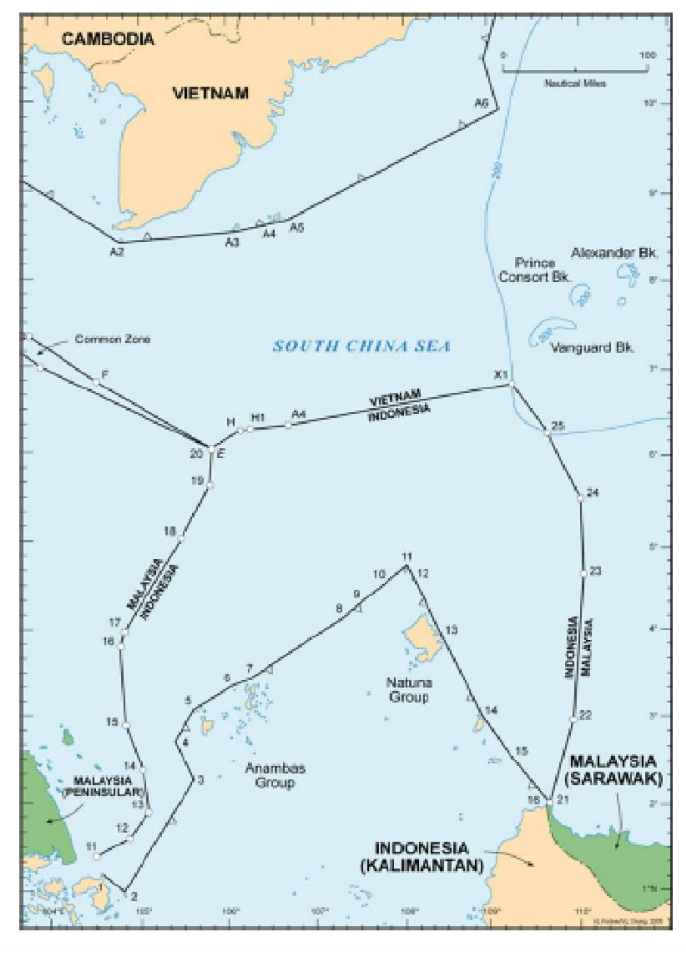

Source: Forbes (2014)

Friction in Natuna with $\mathrm{C}$ hina is an intriguing variable which exposed the geopolitical context of this article. In the Jokowi administration, the relations between Indonesia and $C$ hina has improved significantly, indicated by 
trade aggregate amounted to U SD 44 billion. In 2016, China investments reached up to $400 \%$, a significant amount compared to the investment in the previous year. ${ }^{6}$ The conflict escalation in $\mathrm{N}$ atuna requires Indonesia to strategically calculates its vis-a-vis position with $\mathrm{C}$ hina. However, in many incidents in Natuna, Jokowi had indicated the strong intention not to compromise about national sovereignty, especially regarding the issue of territorial boundaries as a problem that should be resolved in a diplomatic manner.

C onstitutively, the growing importance of realism will trigger the claimant states in the South China Sea to interpret the conflict in the same realistic way. In this case of fish theft in $\mathrm{N}$ atuna waters, $\mathrm{C}$ hina often behaves reactively. If all agents respond the conflict in the region through realism paradigm, the international structure in the surrounding region will be formed under the realism paradigm as well. This is because of the disbelief between agents under the same interest. Related to the contestation in the South China Sea, this article requires thorough and careful analysis because countries in the region will also conduct a comprehensive analysis of Indonesian policy in $N$ atuna water. Every single interaction in the waters will determine the position of claimant states in the South China Sea in the wider context; the conflict resolution for the longestablished conflict in the territory.

THE IMPLICATION OF INDONESIAN POLICY UNDER THE COMPLEXITY OF REGION MARITIME CONFLICT

Indonesian assertive behaviour toward illegal fishing in Natuna waters evoked criticism from experts. "O ne perennial complaint about Yudhoyono when he was in power was his indecisiveness. President Jokowi wants to be perceived as a decisive person, who does not always dance to the tune of big power politics. He will soon find out whether, in an interdependent world, a reclusive nationalist is ableto navigate through the rough seas all alone" (H amzah, 2015: 16). Indonesian effort to accomplish the agenda of World Maritime Axis appear as a strong and firm policy after the implementation of 'Sink the Vessels' policy for all fish theft activities in Indonesian waters.

Since D ecember 2014, foreign vessels caught to collect fish illegally were seized. M any of them were being sunk or being dramatically exposed to be captured by the media. Voting revealed that the act is one of the most popular Jokowi's policies. Indonesian decision to firmly execute the policy was aimed to secure the maritime resources, as stated by Susi Pudjiastuti as the Minister of Marine Affairs and Fisheries, "I am not talking about the territorial authority, but about maritime resources and fish. Fish in our EEZ is our fish" (Tempo, 2016, para. 2). The policy, indeed, ignited a strong reaction from the states who own the vessels. The cases are mainly found in N atuna waters. Pudjiastuti also stated that the biggest illegal fishing happened in $\mathrm{N}$ atuna.

N atuna I slands are located in Karimata Strait, the northern part of Indonesia. The islands consist of small islands which share borders with Malaysia, Singapore, and Vietnam (Tim Pusat Studi Pancasila U G M , 2015). The initial observation of the research captured that Natuna experienced the most frequent border violation, for instance, IU U Fishing by foreign vessels. Several states recorded as the most frequent offender are China, the Philippines, $M$ alaysia, and Thailand. This can be seen from the record of sinking vessels during 2015, especially because of $N$ atuna has abundant marine resources.

The estimation of marine resources in Indonesia reaches 6.6 million tons per year, consisting of 4.5 million tons in Indonesian waters and 2.1 million tons in EEZ waters. The number includes various types of fish, including pelagic fish (3.5 billion tons), coral fish is $0.048 \mathrm{mil}$ lion ton per year. Indonesian waters are also estimated as a home for 3,000 types of fish (Statistic D ata C enter and Information from Ministry of M arine Affairs and Fisheries, 2015). The various types of fish do not al ways refer to the abundant amount of each type of fish. Several types of fish such as sardinella lemuru fish, decapterus fish, and skipjack tuna fish were identified as a type of fish with a big population (Statistic Data Center and Information from M inistry of M arine Affairs and Fisheries, 2015).

Administratively, $N$ atuna shares its northern and eastern borders with the South C hina Sea; southern border with Bintan District; western border with $M$ alaysian peninsula. Fishing is the main activity recorded in $\mathrm{N}$ atuna. In 2015 , fisheries production amounted to $48,698.84$ tons while fish from cultivation amounted to 754.84 ton. The 
growth of fish capture increased $2.87 \%$ in 2015 compared to the previous year. At the same time, the number of fish farming production declined to $69.55 \%$ (Statistic D ata Center and Information from M inistry of $M$ arine Affairs and Fisheries, 2015).

The number, however, was small compared to the data of saltwater fish in Natuna. Data from Riau Province re vealed that in 2011, the fisheries production amounted to $504,212.85$ ton per year with the amount of allowed capture $(80 \%$ of the natural resources potential) was 403,370 ton (Bappeda Keppri, 2018). M arine capture fishery commodity in $\mathrm{N}$ atuna is classified into two categories, pelagic fish and sardinella lemuru fish as it also contributes to the highest of fish population in Indonesia (Statistic Data Center and Information from M inistry of $M$ arine Affairs and Fisheries, 2016). Susi Pudjiastuti also stated that the potential of fish capture in N atuna could reach 400,000 ton per year or equal to U SD 400 million (Kompas, 2016). The potential offered by $N$ atuna has triggered attention from surrounding states to exploit the marine resources in $\mathrm{N}$ atuna waters, making $\mathrm{N}$ atuna as one of the biggest targets of illegal fishing.

As explained by Febrica (2017), according to various Indonesian government documents emphasise four pivotal maritime issues in Indonesian waters (cf. Dewan Maritim Indonesia, 2007; Indonesian Coordinating M inistry for Political, Legal and Security Affairs, 2008; Indonesian MFA, 2004; Indonesian Ministry of State Secretariat, 2008; Sudrajat, 2005; Suristyono, 2005), namely illegal fishing, illegal migrants travelling through its waters, maritime border issues, and smuggling. Therefore, Indonesia is exposed to threetypes of transnational crime. The first threat is smuggling including illegal logging, fuel and sand smuggling, and illegal fishing. The second identified threat is airplane hijacking, sabotage, and espionage of Indonesian territory. The third possible threat is a disruption in Indonesian borders such as arms smuggling, drug smuggling, and human trafficking. In the case of illegal fishing, the maritime security approach used is categorised into non-traditional security. In the contemporary geopolitical environment, maritime security has emerged as one of the most significant elements of global and human security (Reveron \& Mahoney-N orris, 2011).
The Marine insecurity that emerges into a tangible threat, in this context, could be analysed through two models: traditional security and non-traditional security. Traditional security threat which previously embroiled state actors has eventually shifted as non-traditional issues which have gained more attention. H owever, observance of traditional security threat could not be simply set aside. Indonesia should be more considerate to the traditional security threat that could appear anytime. Furthermore, Indonesia still has unfinished tasks related to water and land border within the territory. The Indonesian Navy recorded 94 border violences by M alaysian warfare ships (U sman \& Din, 2009).

Based on the conceptual review, illegal fishing in Indonesian waters appears as a non-traditional security threat and leads to maritimeinsecurity. $\mathrm{H}$ owever, in $\mathrm{N}$ atuna contestation, Indonesia shows assertive behaviour by stressing the need to protect $\mathrm{N}$ atuna-with military force if necessary-instead of responding it as a common maritime sources theft by non-state actors. Indonesia considers that its sovereignty has been violated and prone to crime and hijack in the sea, as stated by one of Indonesian $\mathrm{N}$ avy officials.

Ministry of Foreign Affairs of Indonesia had issued a caveat to protest about the issue (BBC Indonesia, 2016). Moreover, President Widodo demonstrated a symbolic warning by conducting a meeting in a warfare ship. This action was interpreted by International Relations experts and the media as a firm resistance toward Beijing (Kusumadewi, 2016). The issue al so received a strong reaction from the Coordinating Ministry for Political, Law, and Security Sector who served at the period, Luhut Binsar Panjaitan. ${ }^{7} \mathrm{H}$ e stressed the importance to strengthen Indonesian naval base in Natuna waters (Tweed, David, \& Brummitt, 2015). Moreover, the M inistry of Defence, Ryamizard Ryacudu promised improvement of Indonesian military power in Natuna for a specific reason: 'to keep the thieves away' (The Straits Times, 2016). The response was perceived as Indonesian assurance to improve its political realism to address the uncertainty of $N$ atuna waters security due to border violation by China. By taking a deeper look on political contestation between states regarding illegal fishing in Natuna waters, it is apparent that 
friction between Indonesia and China had occurred frequently due to intensive exposure from national and international mass media. In fact, $\mathrm{C}$ hina is not the only state who violate Indonesian territorial border. Neighbouring states such as M alaysia and V ietnam also heavily involved in the polemic.

A nother aspect that needs to be considered is that 317 vessels had been sunk due to illegal fishing since 0 ctober 2014 until A pril 2017. 142 Vessels originated from Vietnam, 76 vessels from the Philippines, 21 vessels from Thailand, 49 vessels from M alaysia, 21 vessels from Indonesia, two vessels from Papua N ew Guinea, one vessel from China, one vessel from Belize, and four vessels have no origin state (Kuwado, 2017). 0 nly one vessel was originated from China and exploded in 0 ctober 2014. This number was much lower than Vietnam vessels that violated Indonesian border and sunk. A nother instance of fish theft in $\mathrm{N}$ atuna happened in 2016 when Chinese vessel Kway Fey 11078 was clearly appeared entering Indonesian EEZ and exploited fish in Indonesian waters. When the ship of M inistry of M arine Affairs and Fisheries were patrolling, the $C$ hinese vessel chased and crashed the fish vessels, so the ship could not be retrieved. This incident was strongly protested by Indonesian M inistry of Foreign A ffairs (BBC Indonesia, 2016). The conflict, however, was not only occurred between Indonesia and China but also between neighbouring countries in EEZ near Natuna waters. The mass media keep broadcasting the amount of Vietnam vessels seized by Indonesian patrol ship in Natuna waters (al-Birra, 2017).

The circumstances in Natuna havelogical consequences toward Natuna security as the closest area to the South China Sea. Therefore, there is an urgency to draw a clear line about Indonesian sovereignty and to solve the delimitation agreement of EEZ with neighbouring countries to maintain Indonesian sovereignty and its maritime security. In order to obtain sovereignty, a state should possess unlimited supreme authority. Jean Bodin stated that sovereignty is "la puissance absolute et perpetuelle d'une republique" (the absolute and perpetual power of a commonwealth). In other words, the absolute power occurs continuously as a manifestation of a state sovereignty. In the authors' point of view, the failure to preserve author- ity, supremacy, and unlimitedness of power will threaten the state's good image whether in international or national perspective.

O bserving the problem in Natuna waters will not be sufficient without domestic framework analysis due to IU U Fishing policy that had been implemented in Indonesian sovereignty border. There is a need for a broader perspective to analyse Indonesian behaviour in the South China Sea conflict. Thus, the initial point is to explain the polemic and put it in the regional security structure context.

From the regional stability perspective, South East A sia region has been known as an unstable region due to the South C hina Sea conflict between China, Vietnam, the Philippines, Malaysia, and Brunei Darussalam. The conflict occurred as a consequence of overlapping claims of the sovereignty of claimant states. Even though ASEAN has attempted many efforts to decrease the probability of conflict through the implementation of D oC, the conflict still could not be resolved peacefully. In contrary, the conflict escalated, and $\mathrm{C}$ hina aggressively builds infrastructure in the South C hina Sea.

China eagerness to expand its geopolitical realism increased the hostility in the South C hina Sea and created a security dilemma. The tendency was apparent from the rise of state's militaryspending in ASEAN and Asian states. ASEAN member states showed the tendency to increase its vigilance as a response to threats posed by $C$ hina. For instance, Vietnam has emerged as the most vocal opponent of $C$ hina's claims in the waterway, where more than USD 3 trillion in cargo pass every year (Reuters, 2017). Reality speaking, ASEAN countries within regional organisation framework still struggle to firmly grasp a common ground towards South C hina Sea dispute (Reuters, 2016). Even though, the newest development shows that ASEA N countries al ready adopted a negotiating framework for a $\mathrm{CoC}$ in the South $\mathrm{C}$ hina Sea, but this move seen by critics as tactic to buy $C$ hina time to consolidate its maritimepower (Reuters, 2017). D eparting from those dynamic political conditions, we could perceive that the realist paradigm still become a major approach towards South C hina Sea dispute and securing national interest became inevitable.

Finally, 'Sink the Vessels' policy towards geopolitics of 
the South China Sea creates a stronger relationship between Indonesia and the conflict of South China Sea. Indonesian assertive manner in $\mathrm{N}$ atuna will strengthen realism structure in the geopolitics of South China Sea conflict. The structure will eventually create agent behaviour in the regional complexity to increase their vigilance. The latest development fits into this broader pattern. In mid of 2017, Indonesia proclaimed that it had renamed a resourcerich northern portion around its Natuna Islands, which lie in the southern end of the South C hina Sea, as the N orth N atuna Sea. The move, which was part of the unveiling of an updated national map that was months in the making, reflects the Southeast Asian state's determination to safeguard its claims even amid the lingering challenges inherent in doing so (Parameswaran, 2017). With this manoeuvre, Jakarta is beckoning that it is eager to take new measures to even more clearly emphasise its firm position that it does not recognise C hina's unilateral ninedash line claim. Thereafter, Beijing responded this manoeuvre by issued a demand for Indonesia to reverse its decision to rename the South $\mathrm{C}$ hina Sea (SCS) waters that lie within Indonesia's EEZ (Jakarta Post, 2017).

According to $C$ hannel News $A$ sia reports, the $C$ hinese Foreign Ministry sent an official note to the Indonesian Embassy in Beijing dated August 25, expressing its opposition to the move. In the letter, C hina said Indonesia's move to change an "internationally accepted name" resulted in the "complication and expansion of the dispute and affects peace and stability." Furthermore, Beijing stated Indonesia's unilateral proclamation could endanger the stable relationship between Indonesia-C hina and halt the progress of South China Sea dispute in a broader context. N onetheless, Indonesian high rank government official did not falter. Shortly after renaming of the area, Maritime Affairs and Fisheries M inister, Susi Pudjiastuti said Indonesia had every right to make the decision. "The N orth $\mathrm{N}$ atuna Sea falls within our territory, not within the South China Sea [...] We have the right [to rename the waters], the N orth N atuna Sea is ours" (Sapiie, 2017, para.3). Buzan (1998: 4) stated that "The internal structure of the Southeast A sian security complex is rather complicated." South East Asia consists of political units which categorized as middle power (in Buzan words: medium-sized powers).
Since there is no hegemonic state in the region, the distribution of power in South East A sia was projected to achieve domestic security instead of formulating agreement at the international level. N evertheless, the rising of $C$ hina has undoubtedly improved its role in South East A sia. ASEAN member states are in dilemmatic position whether to maintain good relations with $C$ hina or to enforce regional solidarity under the stream of South C hina Sea conflict. Indonesia, however, shows trajectory shift in performing its role to develop a firmer region fragmentation. Therefore, Indonesian IU U Fishing policy becomes essential. This article concludes that the decision is precise, considering the nature of Indonesian foreign policy under President Joko Widodo who stressed the importance of domestic interest instead of international orientation in implementing their policy.

\section{CONCLUSION}

This article explained that claim of IU U Fishing Policy has created a security dilemma and restored the anarchy nature in $\mathrm{N}$ atuna waters, though which the nature of anarchy itself can contain conflictual and rational perspectives. Not every country showed reactive response like China did when their vessels were sunk. For instances, Vietnam and Malaysia chose to react based on the threat of the South C hina Sea conflict which appears to be far from the conflict resolution. The geopolitics of the South China Sea after IU U Fishing was implemented could not be separated from states interpretation of territory, natural resources, and distribution of power. Many conflicts had occurred from the intersection of the three aspects, thus it is important to put them into consideration in the future.

As a conclusion, security in the South China Sea needs to be taken into account by the Indonesian government to enforce Indonesian defence in Natuna waters. It is important to include $\mathrm{N}$ atuna local officials to participate in guarding the border area, so $\mathrm{N}$ atuna could be maintained as one of security axes in Indonesian border. The recommendation is based on our analysis of IU U Fishing Policy in N atuna waters. The policy created a bolder real ism structure of the international system in the South C hina Sea. Finally, Indonesia needs to enhance the local capacity to 
support Indonesian foreign policy in the utmost synergic and strategic way.

\section{ENDNOTES}

1 See Hayton (2014: 58) for a comprehensive historical explanation about Chinese government claimed this semi-enclosed water. Whereas, in May 1947 the Chinese parliament approved a motion calling on the government to recover all the Paracels from France, by force if necessary, and to clearly 'delimit our territory.' Thereafter, the Chinese Geography Department of the $M$ inistry of Internal Affairs drafted a list of new names for all the islands in the South China Sea.

2 See Beckman (2014: 58) for further explanation about the Philippines' statement of claim regarding South China, that is, Scarborough Shoal and three islands that are within the Kalayaan Island Group (KIG) claimed by the Philippines (these being Johnson Reef, Cuarteron Reef, and Fiery Cross Reef).

3 In International Politics, there are three types of state status: major, middle, and small power. The traditional preference in determine the status was based on material aspect such as geography, demography, natural resources, economy, military, and many more. The aggregation of all factors created national power in international stage. The related reference to support the explanation is available on Holbraad (1984: 74), Middle Powers in International Politics.

4 See related discussion about foreign politic inheritance in SBY on Emirza Adi Syailendra, Indonesia's Post-Election Foreign Policy: New Directions? RSIS Commentaries No. 113/2014. It was portrayed that the step taken was SBY personal endeavour who wish to be recognised among the world leaders.

5 See Foreign M inistry Spokesperson Hua Chunying's Remarks on Indonesian Navy Vessels Harassing and Shooting Chinese Fishing Boats and Fishermen, 19 June 2016.

6 The improvement of Indonesia and China bilateral relations in economic field is a determinant factor which increases the complexity in Natuna. The consideration to behave firmly on border violation still need to regard China as the second biggest economic power in the world who has substantial contribution to achieve Indonesian goal to be the world maritime axis.

7 Panjaitan currently serves as Coordinating Ministry of M aritime Affairs.

\section{REFERENCES}

Acharya, A. (1995). The Periphery as the Core: The Third World and Security Studies. York Centre for International and Security Studies, (28), pp. 5-6.

Agnew, J. \& Crobridge, S. (2002). Mastering Space: Hegemony, Territory and International Political Economy. London: Routledge.

Al Birra, F. (2017, 24 March). Hiu Macan Tangkap 13 Kapal Vietnam di Laut Natuna. Jawa Pos. http://www.jawapos.com/ read/2017/03/24/118350/hiu-macan-tangkap-13-kapalvietnam-di-laut-natuna (Accessed 8 M ay 2017).
Amindoni, A. (2015, 30 October). Indonesia Sinks 106 Foreign Boats. The Jakarta Post. http://www.thejakartapost.com/news/ 2015/10/30/indonesia-sinks-106-foreign-boats.html (Accessed 13 May 2017).

Anh, N. T. L. (2014). Origins of the South China Sea Dispute. In Huang, J. and Billo, A. eds., Territorial Disputes in the South China Sea, pp. 15-35. Palgrave Macmillan: London.

Ashley, R. K. (1989). Imposing International Purpose: Notes on a Problematic of Governance. In Ernst - Otto Czempiel and James N. Rosenau, eds., Global Changes and Theoretical Challenges: Approaches to World Politics for the 1990s. pp. 251-91. Lexington, MA: D.C. Heath.

Asia Pacific Regional Security Assessment. (2016). Chapter Six: Regional Maritime Security Initiatives. IISS, 27 May 2016. https://www.iiss.org/en/publications/strategic dossiers/issues/ asia-pacific-regional-security-assessment-2016-2288/rsa16-08chapter-6-9273 (Accessed 28 June 2017).

Bappeda Keppri. (n.d.) Sektor Perikanan. http:// bappeda.kepriprov.go.id/index.php/data-informasi/potensidaerah/47-potensi-daerah/201-sektor-perikanan (Accessed 10 June 2017).

BBC. (2016). Menlu RI Protes Aksi Kapal Penjaga Pantai Cina di Wilayah Indonesia. BBC Indonesia, 21 March 2016. http:// www.bbc.com/indonesia/berita indonesia/2016/03/ 160321_indonesia_kemlu_kapal_cina (Accessed $8 \mathrm{M}$ ay 2017).

Beckman, R. C. (2015). The Philippines vs. China Case and the South China Sea Disputes. In Huang, J. and Billo, A. eds., Territorial Disputes in the South China Sea, pp. 54-65. Palgrave Macmillan: London.

Buzan, B. \& Waever, O. (2003). Regions and Powers: the Structure of International Security (Vol. 91). Cambridge: Cambridge University Press.

Buzan, B. (2008). People, States \& Fear: An Agenda for International Security Studies in the Post-Cold War Era. Colchester: Ecpr Press.

Buzan, B., Wæver, O., \& Wilde, J. De. (1998). Security: A New Framework for Analysis. London: Lynne Rienner Publishers.

Cavelty, M. D. \& Mauer, V. (2010). The Routledge Handbook of Security Studies. New York: Routledge.

Chan, F. (2016). Bigger Defence Budget for Jakarta, SE Asia News. The Straits Times, 29 June 2016. http://www. straitstimes.com/ asia/se-asia/bigger-defence-budget-for-jakarta (Accessed 8 May 2017).

Chapsos, I. \& Malcolm, J. A. (2017). Maritime Security in Indonesia: Towards a Aomprehensive agenda? M arine Policy, 76, pp.178184.

Chapsos, I. (2016). Is Maritime Security a Traditional Security Challenge? In Exploring The Security Landscape: NonTraditional Security Challenges, ed. Masys, A.J. Advanced Sciences and Technologies: 59. Switzerland: Springer.

Chatterjee, A. (2014). Non-traditional Maritime Security Threats in the Indian Ocean Region. Maritime Affairs: Journal of the National M aritime Foundation of India, 10 (2), pp. 77-95.

Christopher, W. \& Meng, Y. (Eds.). (2011). Security Studies: A Reader. Oxon: Routledge.

Connelly, A. L. (2015). Sovereignty and the Sea: President Joko 
Widodo's Foreign Policy Challenges. Contemporary Southeast Asia: A Journal of International \& Strategic Affairs, 37(1), pp. 1-28.

Connelly, A. L. (2017, April). Indonesia di Laut Cina Selatan: Berjalan Sendiri. https://www.lowyinstitute.org/publications/ indonesia-laut-cina-selatan-berjalan-sendiri (Accessed $10 \mathrm{M}$ ay 2017).

Corbett, J. (1911). Some Principles of Naval Strategy. London: Longman, pg.

Dabova, E. L. (2013). Non-traditional Security Threats in the BorderAreas: Terrorism, Piracy, Environmental Degradation in Southeast Asian Maritime Domain. International Archives of the Photogrammetry, Remote Sensing and Spatial Information Sciences, 40, pp. 51-56.

Deny, S. (2015). M enteri Susi Ungkap Buruknya Praktik Pencurian Ikan di Indonesia. Liputan6, 11 December 2015. http:// bisnis.liputan6.com/read/2387745/menteri-susi-ungkapburuknya-praktik-pencurian-ikan-di-indonesia (Accessed 10 May 2017).

Detik News. (2010, 15 August). SBY Minta Penangkapan 3 Petugas DKP Diselesaikan Baik-baik. DetikNews. https://news.detik.com/ berita/d-1420851/sby-minta-penangkapan-3-petugas-dkp diselesaikan-baik-baik (Accessed 13 May 2017).

Dewan Maritim Indonesia. (2007). Laporan: Perumusan Kebijakan Grand Strategi Pembangunan Kelautan. Jakarta: Sekretariat Jenderal Departemen Kelautan dan Perikanan.

Djalal, H. (2006). The Emergence of the Concept of Fishing Entities: A Note. Ocean Development \& International Law, 37(2), pp. 117-121.

Djalal, H. (2012). Indonesia's M aritime Challenges and Priorities. In Sam Bateman and Joshua Ho, M aritime Challenges and Priorities in Asia: Implications for Regional Security 21. Routledge.

Djumala, D. (2014, 15 September). Ketika Diplomasi Membumi. Kompas. http://internasional.kompas.com/read/2014/11/15/ 05320031/Ketika.Diplomasi.M embumi (Accessed 13 May 2017).

Dodds, K. (2001). Political Geography III: Critical Geopolitics after Ten Years. Progress in Human Geography, 25(3), pp. 469-484.

Dodds, K. (2015). Fish and Continental Shelves: Maritime Security, Sovereignty, and Stewardship in the Polar Regions. Brown Journal of World Affairs, xxii(I), pp. 1-22.

Emmers, R. (2009). Geopolitics and Maritime Territorial Disputes in East Asia. Oxon: Routledge.

Energy Information Administration. (2013, 3 A pril). Contested Area of South China Sea Likely Have Few Oil and Gas Resources. https://www.eia.gov/todayinenergy/detail.php? id = 10651 (Accessed 29th October 2018).

Febrica, S. (2017). Maritime Security and Indonesia: Cooperation, Interests and Strategies. New York: Taylor \& Francis.

Forbes, V. L. (2014). Indonesia's Delimited M aritime Boundaries. Heidelberg: Springer.

Furtado, X. (1999). International Law and the Dispute over the Spratly Islands: Whither UNCLOS? Contemporary Southeast Asia, 21(3), p. 386.

Giddens, A. (1986). The Constitution of Society: Outline of the
Theory of Structuration (Vol. 349). California: Univ of California Press.

Gindarsah, I. \& Priamarizki, A. (2015, A pril). Indonesia's M aritime Doctrine and Security Concerns. RSIS Policy Report 9. RSiS Nanyang Technology University, p.15.

Hamzah, B. B. A. (2015). Sinking the Ships: Indonesia's Foreign Policy under Jokowi. RSIS Commentary 16. RSiS Nanyang Technology University.

Hasibuan, A. N. (2014, 29 November). Menkopolhukam Bela Kebijakan Jokowi Tenggelamkan Kapal Ilegal. CNN Indonesia. http://www.cnnindonesia.com/nasional/20141129064351-2014664/menkopolhukam-bela-kebijakan-jokowi-tenggelamkankapal-ilegal/ (Accessed 4 June 2017).

Hayton, B. (2014). The South China Sea: The Struggle for Power in Asia. Yale University Press.

Heazle, M. \& Butcher, J. G. (2007). Fisheries Depletion and the State in Indonesia: Towards a Regional Regulatory Regime. Marine Policy, 31(3), pp. 276-286.

Hikmah, M. (2013). Illegal Fishing in Indonesia from the National and the International Law Perspective. Indonesian Journal of International Law, 11(1), pp. 1-29.

Ho, J. \& Raymond, C. Z. (2005). The Best of Times and the Worst of Times M aritime Security in the Asia Pacific. World Scientific: Institute of Defence and Strategic Studies, xvi, p. 294.

Holsti, K. J. (1970). National Role Conceptions in the Study Role Conceptions National of Foreign Policy. International Studies Quarterly, 14(3), pp. 233-309.

Hongzhou, B. Z. (2015). Indonesia's War on Illegal Fishing/ : Impact on China. RSIS Commentaries, 192.

Hudson, V. M. (2005). Foreign Policy Analysis: Actor specific Theory and the Ground of International Relations. Foreign Policy Analysis, 1(1), pp.1-30.

Indonesian Coordinating M inistry for Political, Legal and Security Affairs. (2008). Evaluasi Pengelolaan Bidang Politik, Hukum dan Keamanan Tahun 2007. Jakarta: Coordinating M inistry for Political, Legal and Security Affairs.

Indonesian Ministry of Foreign Affairs (M FA). (2004). Forum Dialog ke XI Kerja Sama Maritim ASEAN. Jakarta: Badan Pengkajian dan Pengembangan Kebijakan.

Indonesian M inistry of State Secretariat. (2008). Pidato Kenegaraan Presiden Republik Indonesia serta Keterangan Pemerintah atas Rancangan Undang-Undang tentang Anggaran Pendapatan dan Belanja Negara Tahun Anggaran 2009 beserta Nota Keuangannya di Depan Rapat Paripurna Dewan Perwakilan Rakyat 15 Agustus 2008. Jakarta: Sekretariat Negara.

Irawan, Y. K. (2016, 7 January). Pangarmabar: Laut Natuna Rawan Kejahatan Perairan. Kompas. http://regional.kompas.com/read/ 2016/01/07/15463041/

Pangarmabar.Laut.Natuna.Rawan.Kejahatan.Perairan. (Accessed 8 May 2017).

Jakarta Post, (2017, 3 September). China Demands Indonesia Drop New Name for Natuna Waters. TheJakartaPost.com. http:// www.thejakartapost.com/news/2017/09/03/china-demandsindonesia-drop-new-name-for-natuna-waters.html (Accessed 13 November 2017).

Kasperson, R. E. \& Minghi, J. V. (2011). eds. The Structure of 
Political Geography. New Brunswick: Transaction Publishers.

Keliat, M. (2009). Keamanan Maritim dan Implikasi Kebijakannya bagi Indonesia. JSP (Jurnal IImu Sosial dan Ilmu Politik), 13(1), pp. 111-129.

Keohane, R. (1988). International Institutions: Two Approaches. International Studies Quarterly, 32(4), pp. 379-396.

Kompas. (2009, 24 June). Perairan Natuna Paling Rawan Pencurian Ikan oleh Kapal Asing. Kompas.com. http:// regional.kompas.com/read/2009/06/24/19111853/ perairan.natuna.paling.rawan. pencurian.ikan. oleh.kapal.asing./ (Accessed 12 May 2017)

Kusumadewi, A. (2016, 23 June). Rapat di Atas Kapal Perang di Natuna, Jokowi Gertak China. CNN Indonesia. http:// www.cnnindonesia.com/nasional/20160623091859-20140309/rapat-di-atas-kapal-perang-di-natuna-jokowi-gertakchina/ (Accessed 8 May 2017).

Kuwado, F. J. (2017). Lagi, 81 Kapal Pencuri Ikan Ditenggelamkan di Penjuru Indonesia. Kompas, 1 April 2017. http:// nasional.kompas.com/read/2017/04/01/12003881/ lagi.81.kapal.pencuri.ikan.ditenggelamkan.di.penjuru.indonesia (Accessed 10 May 2017).

Liputan6. (2010). Presiden: Selesaikan Kasus KKP dengan Diplomasi. Liputan 6.com. http://news.liputan6.com/read/ 291462/presiden-selesaikan-kasus-kkp-dengan-diplomasi (Accessed 13 May 2017).

Madanayaka, S. (2015). Illegal Fishing Issue as a Non-traditional Security Threat to Sri Lanka (With Reference to India). Paper presented at Proceedings of 8th International Research Conference, KDU, pp. 72-78.

Malaisiakini. (2010, 25 August). KL "Out of Patience" after Indonesia Protests. https://www.malaysiakini.com/news/141087 (Accessed 13 May 2017).

Mandel, R. (1984). The Desirability of Irrationality in Foreign Policy Making: A Preliminary Theoretical Analysis. Political Psychology, pp. 643-660.

Merriam, C. (1900). History of the Theory of Sovereignty since Rousseau. New Jersey: The Law Book Exchange, Itd.

Mogato, M., Martina, M., \& Blanchard, B. (2016, 25 July). ASEAN Deadlocked on South China Sea, Cambodia Blocks Statement. Reuters. https://www.reuters.com/article/us-southchinasearuling-asean/asean-deadlocked-on-south-china-sea-cambodiablocks-statement-idUSKCN1050F6 (Accessed 13 November 2017).

Nainggolan, P. P. (2015). Kebijakan Poros Maritim Dunia Joko Widodo dan Implikasi Internasionalnya. Politica, 6(2), pp. 167190.

Negara, S. \& Das, S. (2017). Challenges for Indonesia to Achieve its Maritime Connectivity Plan and Leverage on Regional Initiatives. ISEAS, 3, pp. 1-11.

Parameswaran, P. (2017, 17 July). Why Did Indonesia Just Rename Its Part of the South China Sea? The Diplomat. https:// thediplomat.com/2017/07/why-did-indonesia-just-rename-itspart-of-the-south-china-sea/ (Accessed 13 November 2017).

Pashakhanlou, A. H. (2016). Realism and Fear in International Relations: Morgenthau, Waltz and M earsheimer Reconsidered. Springer.
Pattiradjawane, R. L. (2017). South China Sea Disputes: Sovereignty and Indonesian Foreign Policy. In The South China Sea Disputes: Flashpoints, Turning Points and Trajectories, pp. 319323. Singapore: World Scientific Publishing.

Pedrason, R., Kurniawan, Y., \& Purwasandi. (2016). Handling of Illegal, Unreported and Unregulated (IUU) Fishing Rodon. Jurnal Pertahanan, 2(1), pp. 13-26.

Presiden Republik Indonesia. (2015, 13 November ). Indonesia Sebagai Poros M aritim Dunia. http://presidenri.go.id/maritim/ indonesia-sebagai-poros-maritim-dunia.html (Accessed 8 May 2017)

Purnomo, N. R. (2017, 7 A pril). Panglima TNI Cek Pelanggaran Kedaulatan Negara oleh Perusahaan Malaysia di Anambas dan Natuna. Tribunnews. http://www.tribunnews.com/nasional/ 2017/04/07/pang lima-tni-cek-pelanggaran-kedaulatan-negaraoleh-perusahaan-malaysia-di-anambas-dan-natuna (Accessed 8 May 2017).

Pusat Data Statistik dan Informasi Kementerian Kelautan dan Perikanan. (2015). Kelautan Dan Perikanan Dalam Angka 2015. Pusat Data, Statistik dan Informasi Kementerian Kelautan dan Perikanan. http://statistik.kkp.go.id/sidatik-dev/Publikasi/src/ kpda2015.pdf (Accessed 8 May 2017).

Pusat Data Statistik dan Informasi Kementerian Kelautan dan Perikanan. (2016). Kelautan dan Perikanan dalam Angka Kabupaten Natuna. Pusat Data, Statistik dan Informasi Kementerian Kelautan dan Perikanan. http://statistik.kkp.go.id/ sidatik-dev/Publikasi/src/natuna.pdf (Accessed 8 May 2017).

Reveron, D. S. (2016). Maritime Security Deficits and International Cooperation Illegal Fishing, Piracy, and M aritime Security Deficits in Southeast Asia. Georgetown Journal of Asian Affairs, pp. 31-36.

Ristian, B. \& Supriyanto, A. (2015). Indonesia's Natuna Islands: Next Flashpoint in the South China Sea? RSIS Commentary, p. 33. RSiS Nanyang Technology University.

Rohingati, S. (2014). Penenggelaman Kapal Ikan Asing: Upaya Penegakan Hukum Laut Indonesia. DPR, VI, p. 24.

Rosyidin, M. \& Andika, M. T. (2017). Indonesia dalam Pusaran Global: Politik Luar Negeri Susilo Bambang Yudhoyono. Yogyakarta: Pustaka IImu.

Rosyidin, M. (2012). Globalisasi dan Paradoks Kepentingan Nasional: Million Friends Zero Enemy. Analisis CSIS, 41(3), p. 414.

Rosyidin, M. (2017). Foreign Policy in Changing Global Politics: Indonesia's Foreign Policy and the Quest for Major Power Status in the Asian Century. South East Asia Research: 25(2), pp. 175-191.

Salim, T. \& Parlina, I. (2015, 12 November). Jokowi to Skip APEC Summit. The Jakarta Post. http://www.thejakartapost.com/ news/2015/11/12/jokowi-skip-apec-summit.html (Accessed 13 May 2017).

Sambhi, N. (2015). Jokowi's 'Global Maritime Axis': Smooth Sailing or Rocky Seas Ahead? Security Challenges, 11(2), pp. 39-55.

Sapiie, M. A. (2017, July18). Indonesia shrugs off China's Protest over North Natuna Sea's Name. Jakarta Post. https:// www.thejakartapost.com/news/2017/07/18/indonesia-shrugsoff-chinas-protest-over-north-natuna-seas-name.html (Ac- 
cessed 13 November 2017).

Sekretariat Negara. (2010, 1 September 2010). Pidato Presiden RI mengenai Dinamika Hubungan Indonesia - Malaysia. http:// www.setneg.someah.id/baca/index/ pidato_presiden_ri_mengenai_dinamika_hubungan_indonesia__malaysia_1_september_2010 (Accessed May 13 2017).

Sheany. (2017, September 8). Indonesia, China and The North Natuna Sea. jakartaglobe.id. http://jakartaglobe.id/news/ indonesia-china-north-natuna-sea/ (Accessed 13 November 2017).

Shepherd, C. \& Mogato, M. (2017, August 6). ASEAN, China Adopt Framew ork for Crafting Code on South China Sea. Reuters. https://www.reuters.com/article/us-asean-philippinessouthchinasea/asean-china-adopt-framework-for-crafting-codeon-south-china-sea-idUSKBN1AM OAY (Accessed 13 November 2017).

Shepherd, C. (2017, August 8). China, Vietnam M eeting Canceled amid South China Sea Tensions. Reuters. https:// www.reuters.com/article/us-asean-philippines-china-vietnam/ china-vietnam-meeting-canceled-amid-south-china-seatensionsidUSKBN1A007K (Accessed 13 November 2017).

Shepherd, L. J. (Ed.). (2013). Critical Approaches to Security: An Introduction to Theories and M ethods. London: Routledge.

Sodik, D. M. (2009). Analysis of IUU Fishing in Indonesia for the Reform of Fisheries Legislative and Institutional Frameworks. Ocean Yearbook Online, 23(1), pp. 309-344.

Sodik, D. M. (2009). IUU Fishing and Indonesia's Legal Framework for Vessel Registration and Fishing Vessel Licensing. Ocean Development and International Law, 40(3), pp. 249-267.

Sudrajat (Direktur Jenderal Strategi Pertahanan Kementerian Pertahanan Indonesia). (2005). 'Kebijakan Kelautan Nasional dari Perspektif Pertahanan dan Keamanan,' in Laporan Kegiatan Diskusi Panel: Mencari Format Kebijakan Kelautan Indonesia dalam Rangka Mendukung Pembangunan dan Integrasi Nasional (Studi Kasus Kanada dan Norwegia), Surabaya, 7-8 April 2005. Jakarta: Kementerian Luar Negeri Indonesia.

Suhartono. (2015, September 30). Indonesia Eyes Seat on UN Security Council. The Jakarta Post. http:// www.thejakartapost.com/news/2015/09/30/indonesia-eyesseat-un-security-council.html (Accessed 20 June 2017).

Suristiyono. (2005). 'Penyelenggaraan Keamanan dan Ketertiban di Kawasan Perairan Selat Malaka,' in Pertemuan Kelompok Ahli Tentang Kebijakan Terpadu Pengelolaan Keamanan Selat Malaka. Jakarta: Badan Pengkajian dan Pengembangan Kebijakan Kementerian Luar Negeri.

Tempo. (2016, August 17). Menteri Susi Kembali Tenggelamkan 60 Kapal Ikan Ilegal. Tempo.co. https://m.tempo.co/read/news/ 2016/08/17/063796704/menteri-susi-kembali-tenggelamkan60-kapal-ikan-ilegal (Accessed 4 June 2017).

Thang, N. D. (2012). Fisheris Co-operation in the South China Sea and (Ir)relevance of the Sovereignty Question. Asian Journal of International Law, 2, pp. 59-88.

Tim Pusat Studi Pancasila UGM . (2015). Membangun Kedaulatan Bangsa Berdasarkan Nilai-Nilai Pancasila: Pemberdayaan Masyarakat dalam Kawasan Terluar, Terdepan dan Tertinggal. Yogyakarta: Pusat Studi Pancasila UGM.
Townsend, G. I. (1998). Preventive Diplomacy and Pro-Activity in the South China Sea. Contemporary Southeast Asia, 20(2), pp. 171-190.

Tweed, D. \& Brummit. (2015, October 8). Indonesia Mulls Drones in Response to China's M aritime Flexing. Stripes.com. https:// www.stripes.com/news/pacific/indonesia-mulls-drones-inresponse-to-china-s-maritime-flexing-1.372344 (Accessed 13 November 2017)

Usman, A. \& Sukma, R. (1997). Konflik Laut Cina Selatan: Tantangan bagi ASEAN. Centre for Strategic and International Studies. Jakarta: Centre for Strategic and International Studies.

Usman, S. \& Din, I. (2009). Heboh Ambalat: Ternyata M alaysia ingin Merebut Sumber M inyak Indonesia. Yogyakarta: Narasi.

VivaNews. (2010, 15 August). Kronologi Malaysia Tangkap 3 Petugas KKP Rl. Viva. http://nasional.news. viva.co.id/news/read/ 171206-ini-kronoligis-penangkapan-petugas-dkp (Accessed 13 May 2017).

Weatherbee, D. E. (2016). Re-Assessing Indonesia 's Role in the South China Sea. ISEAS, 18, pp. 1-13. 